Man and Nature

L'homme et la nature

\title{
'Storms of Sorrow': The Poetry of Helen Maria Williams
}

\section{Deborah Kennedy}

Volume 10, 1991

URI : https://id.erudit.org/iderudit/1012625ar

DOI : https://doi.org/10.7202/1012625ar

Aller au sommaire du numéro

Éditeur(s)

Canadian Society for Eighteenth-Century Studies / Société canadienne d'étude du dix-huitième siècle

ISSN

0824-3298 (imprimé)

1927-8810 (numérique)

Découvrir la revue

Citer cet article

Kennedy, D. (1991). 'Storms of Sorrow': The Poetry of Helen Maria Williams. Man and Nature / L'homme et la nature, 10, 77-91.

https://doi.org/10.7202/1012625ar

Copyright (C Canadian Society for Eighteenth-Century Studies / Sociéte canadienne d'étude du dix-huitième siècle, 1991
Ce document est protégé par la loi sur le droit d'auteur. L'utilisation des services d'Érudit (y compris la reproduction) est assujettie à sa politique d'utilisation que vous pouvez consulter en ligne.

https://apropos.erudit.org/fr/usagers/politique-dutilisation/ 


\section{8. 'Storms of Sorrow': The Poetry of Helen Maria Williams}

For Helen Maria Williams, sensibility was not just a poetic fashion but a life-long creed that formed an important part of her liberal Protestant faith. Even though Dissenters such as Williams prized rationality and the empirical pursuit of knowledge, the current philosophical interest in emotions and morals was relevant to their own fight for individual liberty and religious freedom. In her book Sensibility, Janet Todd explains that the Dissenters' 'libertarian concerns were reinforced by the sentimental interest in the deprived. The most famous Dissenting divines rarely wrote sentimental literature, but they were certainly its consumers, and they encouraged many to produce it. ${ }^{\prime \prime}$

Williams was a protegé of the well-known Dissenter Andrew Kippis, who, as she recounts in her memorial verses to him, taught her 'in the house of prayer ${ }^{2}$ when she was a child, and then helped her to discover her literary vocation when he assisted her with her first publication, Edwin and Eltruda (1782). This was one of the poems she revised for the collection which secured her reputation as a bright young poet of the 1780s, her two volume Poems of $1786,{ }^{3}$ which also included several sonnets, odes, long political poems, and religious verse. Sincere and guileless, Williams confronts again and again familial grief and life wasted in warfare, slavery, or poverty.

The title of my paper, 'Storms of Sorrow,' comes from the hymn 'While Thee I Seek Protecting Power' (1:97-99), which was subsequently reprinted in several hymn collections including Priestley's and Kippis's and in a number of nineteenth-century Unitarian hymnals. This alliterative and assonant phrase aptly defines what one usually thinks of as the excesses of literature of sensibility: the storms of sorrow and all those drenched handkerchiefs! But Williams's hymn promotes spiritual fortitude, not emotional excess:

In every joy that crowns my days,

In every pain I bear,

My heart shall find delight in praise,

Or seek relief in prayer. 
When gladness wings my favour'd hour,

Thy love my thoughts shall fill:

Resigned when storms of sorrow lower,

My soul shall meet thy will. (1:98)

These stanzas advocate an attitude of faith in what Williams calls God's 'ruling hand' (1:98) and 'protecting power' (1:97). Her hymn is the song of a believer drawing on inner strength to meet the instability of life: 'My steadfast heart shall know no fear - / That heart will rest on Thee!' (1:99). Assured of the religious nature of sensibility, Williams rejected what Syndy McMillen Conger has called the increasingly secular kind of sensibility that had become fashionable in some circles in England by the 1780s. ${ }^{4}$ Conger cites Lady Eglantine Wallace as one writer who identified sensibility 'unequivocally as a New Testament virtue. ${ }^{5}$ Similarly, M. Ray Adams argues that Williams's 'sentimentalism was deeply rooted in a religious nature. ${ }^{6}$ The 'storms of sorrow' represent the emotional response to injustice or suffering of any kind, and in the late eighteenth century, those storms overflowed into political action, which for Williams and many others was guided by religious conscience.

Liberal sentiments ran high in the 1780 s, and Williams's poetry appealed to the taste of a majority of the reading public. She welcomed the French Revolution and moved to France in 1792, where she remained most of her life. She was well known there and in England and America for her poetry, fiction, translations, and political journalism. But as popular support for the Revolution waned, an increasingly conservative British press attacked her for her political stance, which was Girondin (not Jacobin), and her personal relationship with John Hurford Stone. However, she remained committed to the cause of liberty and raised two nephews who became prominent Protestant leaders in Paris and Amsterdam. The woman to whom Wordsworth addressed his first published poem - 'Sonnet on Seeing Miss Helen Maria Williams Weep at a Tale of Distress' (1787) - integrated sensibility with her religious and political ideals in her early poetry and her life's work. ${ }^{7}$

In his attempt to define the age of sensibility, Northrop Frye posits a range of emotional states from animism to human sympathy characteristic of the literature of this type. ${ }^{8}$ Williams's poetry fits Frye's description well, and it is not surprising that the ballad revival and the popularity of Ossian, one of her favourite writers, greatly shaped her own style. Williams could justify her entry into the male world of the poetic vocation because she wrote at a time when simple emotional expression had aesthetic value. In her 'Epistle to Dr. [John] Moore' she states: 'I mean no giddy heights to climb/ And vainly toil to be sublime/. 
... My heart instructs me how to write' (2:4). Trusting in the sentiments of her own heart, she aligns herself with the ballad writers and with Ossian, whose work Hugh Blair called 'The poetry of the Heart.' Though ignorant of religious ideas, 'Ossian felt strongly himself; and the heart when uttering its native language never fails, by powerful sympathy, to affect the heart. ${ }^{10}$ Blair's comments demonstrate a faith in the value of sympathetic sensibility, which, as Stephen D. Cox has explained, developed during the eighteenth century largely through the work of philosophers such as the Earl of Shaftesbury, David Hume, and Adam Smith. ${ }^{11}$ Though she lacked the benefits of a formal education or what Virginia Woolf was later to call, ${ }^{12}$ alluding to Thackeray's Pendennis, 'Arthur's Education Fund' - Williams could still legitimately enter the public sphere as a poet of sensibility and, as in the quotation above, she presented her credentials as those of the heart, not the head, consciously excluding herself from the more intellectual arena reserved for talented and educated men. ${ }^{13}$ Hester Thrale Piozzi wrote a telling comment in her journal of 26 February 1789 in which she describes the kind of verse that had become popular:

This Fashion makes well for us Women however, as Learning no longer forms any part of the Entertainment expected from Poetry - Ladies have therefore as good a Chance as People regularly bred to Science in Times when fire-eyed Fancy is said to be the only requisite of a Popular Poet $-\&$ accordingly I do think Helen Maria Williams has distanced all her Competitors in Lines upon the Slave Trade. ${ }^{14}$

Piozzi ironically points out that women could at least enjoy temporary popularity while feeling rather than knowledge was in vogue.

The collection of 1786 is dominated by three lengthy poems which criticize the tragic effects of war, particularly the devastation of families. Edwin and Eltruda deals with families divided during the War of the Roses; An American Tale with families divided by the American revolution; and Peru with the Spanish massacre of the Incas. Williams purposely distances herself from those bards who sing of martial strife, saying that such a theme does not suit 'her reed' (1:78). Depicting the domestic scenes causes some problems because she attempts to apply an abstract view of human relationships to the divergent settings. Although occasioned by specific political events, the familial tableaux could be interchangeable. Williams projects onto her characters emotional responses that are the same for an English woman of the fifteenth century, an English woman of the eighteenth century, and Peruvian women of the sixteenth century. She fails to recreate the historical 
scenes, but her aim was to depict and speak to a reality of the human heart that would transcend historical conditions.

In choosing to write poetry that did not celebrate war, Williams aligns herself with other pacifist poets, ${ }^{15}$ such as John Scott, whose memorable 'Ode XIII' is still anthologized:

I hate that drum's discordant sound,

Parading round, and round, and round:

To me it talks of ravag' $d$ plains,

And burning towns, and ruin'd swains,

And mangled limbs, and dying groans,

And widows tears and orphans moans. ${ }^{16}$

Along with emphasizing human suffering rather than glorifying military prowess, the anti-war poetry of the period of the American Revolution portrayed men who were forced to fight against their relatives who had immigrated. 'An Ode to Mars,' published anonymously in London in 1778, condemns the calamities of civil war which make 'kindred wet with kindred blood' and sons butchers to the Sire. ${ }^{17}$ Similarly, William Blake in Poetical Sketches (1783) scathingly portrays the human slaughter in his 'Prologue to King John': 'full oft did Patriot rise, when Tyranny hath stain'd fair Albion's breast with her own children's gore. . . . Brother in brother's blood must bathe. . . . The trembling sinews of old age must work the work of death against their progeny. ${ }^{18}$ Referring to past civil war, and scenes of family members killing family members, both Blake and Williams obviously allude to the British war against America, which ended only in 1783.

In both Edwin and Eltruda and 'An American Tale,' the young woman's lover and her father literally take up opposing sides, and the dilemma of the daughter demonstrates the inevitable human suffering caused by war. In Edwin and Eltruda, Eltruda's father, Albert, takes up the cause of the Lancasters, and Eltruda's lover, Edwin, fights for the side of York. During a skirmish, Albert is mortally wounded, and his assailant - actually Edwin - comforts him as he dies but is naturally horrified when he realizes who the dying man is. When Edwin tells Eltruda of the tragedy, she dies of grief and he soon follows her. This outcome is in keeping with what John Butt defines as the Sentimental Ballad of the period, in which 'a happy ending is rare. ${ }^{19}$ For example, in two popular ballads, David Mallet's 'William and Margaret' (1724) and Thomas Tickell's 'Lucy and Colin' (c. 1716), young lovers suffer betrayal and death. In the first, Margaret's ghost returns to torment William, who broke his oath to her, and the ballad ends with William lying speechless 
(dead?) on her cold grave. In the second poem, Lucy too has been betrayed by Colin who marries a wealthier woman. Lucy dies of grief the day before Colin's wedding, and he dies just after the marriage takes place. In Edwin and Eltruda the situation is not the usual one of jilted lovers, even though the results are the same. Innocent of temptations of money and lust, Edwin and Eltruda experience 'Domestic bliss, unvex' $\mathrm{d}$ by strife' (1:69), until political turmoil intervenes: 'the fatal day ... When York from Lancaster's proud sway,/ The regal sceptre claim'd' (1:73). Williams shows that while war legitimizes killing on the battlefield, its effects extend far beyond that to the domestic sphere. In Edwin and Eltruda the death of the father leads to Eltruda's death, even though she is safely away from the actual combat. Eltruda was a peaceful young woman who devoted herself to relieving the suffering of those around her:

For the bruis'd insect on the waste,

A sigh would heave her breast;

And oft her careful hand replac'd

The linnet's falling nest.

Full oft with eager step she flies

To cheer the roofless cot,

Where the lone widow breathes her sighs,

And wails her desp'rate lot. (1:69-70)

Williams idealizes this resourceful woman of feeling, so that Eltruda seems a character in a parable. The simplicity of the diction adds to this effect. While Williams draws on stock phrases of the period, she creates a unique impression with details, such as the 'bruis' $d$ insect' and 'the careful hand.' Eltruda can alleviate suffering in her community, but she is powerless to stop the war. When she learns that her lover unknowingly killed her father on the battlefield, she dies of grief, but still hopes to meet Edwin in the afterlife. She does not have to wait long, because Edwin soon feels 'within his shivering veins/ A mortal chillness rise. . . and on her bosom dies' (1:93). Indeed, one of the more disturbing aspects of literature of sensibility is that death provides a convenient end for men and women of feeling. Whether through illness, as with Henry MacKenzie's Harley, or through suicide, as with Goethe's Werther, an early death seems the dubious reward for sensitive human beings.

In 'An American Tale,' also written in a ballad style, Amelia's father fights for the British and her lover, Edward, fights for the Americans. Amelia has no say in the waging of war but she is not protected from its 
carnage. Her role is confined to waiting for the outcome and then caring for the casualties. She acts courageously, risking her own life to tend to her dying father: 'An aged father's wound to heal/ Through scenes of death I flew' (1:3). Amelia's anxiety and her sense of self-sacrifice are expressed in the best stanza of the poem, which has the heightened tension of an incantatory ballad refrain:

'Perhaps my hast'ning steps are vain,

'Perhaps the warrior dies! -

'Yet let me sooth each parting pain -

'Yet lead me where he lies' — (1:4)

In a parallel manner, by focusing on domestic scenes, Williams too gains entry to the field of battle, usually reserved for men. But Amelia almost suffers the typical fate of a ballad heroine, nearly dying from grief over the supposed death of her lover, until he miraculously reappears. Wounded in the field, Amelia's father is tended to by an unknown American soldier who turns out to be Amelia's lover, Edward. These domestic coincidences allow Williams to show that all share a common humanity. If one can be merciful to the enemy, even love and marry the enemy, then maybe peace can be restored. Edward's 'love of human kind' enables him to forget that the wounded old man is his foe; and Amelia's father does not see him as the enemy but as 'a gentle youth, with pitying care' (1:6). Williams posits, rather tenuously, an idealistic humanitarianism which will triumph over any worldly strife.

Ironically, this idealism is lacking in the one poem from the 1786 collection which both The Monthly Review and The European Magazine raved about, Williams's grisly ghost story 'Part of an Irregular Fragment, Found in a Dark Passage of the Tower.' It was not so unusual for a rational Dissenter to write about ghosts, because as Patricia Meyer Spacks has documented in The Insistence of Horror (1962), by the end of the eighteenth century ghosts were popular narrative subjects, and supernatural themes were used 'without apology or qualification. ${ }^{20}$ Williams's 198-line poem was reprinted in the Monthly Review, and the reviewer's comments show that Williams continued to arouse pathos and, in this poem, appealed to popular fascination with gothic horror:

Among the more striking beauties of this poem, we must particularly notice.... In the 6th stanza, the pathetic idea of the infant telling his absent mother his distress: and, in the 8th, the description of a mother and her infants perishing with hunger, and the freezing power of fixed despair. A wildness and horror run 
through this whole piece, which arrest the Reader's imagination, and chill the heart with 'grateful terrors. ${ }^{21}$

In her 'Advertisement,' Williams explains that she was inspired to write the poem after seeing a drawing done by a young man who had visited the Tower, seen a locked door, and then imagined what murders may have been committed within. Williams's opening comment suggests that she was quite aware of the Burkean tradition in which her poem, 'formed on a very singular and sublime idea' (2:23), could be placed. The very title of the poem indicates that it fulfils one of Edmund Burke's requirements for terror-inducing art, namely obscurity. The document is part of something irregular, which is a fragment of we know not what, found by we know not whom, in an unidentified dark passage in that national site of crime, punishment, and concealment - the Tower. This bibliographical obscurity itself intensifies the horror of the story of the ghosts. The form of the poem is also irregular, being divided into ten unequal and metrically variable parts and ending with an ellipsis signalling a torn manuscript. As if on a modern tour through a haunted house, the visitor to the Tower is accosted by one ghost after another, and the incomplete text implies that the visitor may be ultimately engulfed by the spectral world. This is another cause for terror because the visitor is an innocent bystander, victimized by the ghosts in the Tower. In other poems, such as Joanna Baillie's 'Night Scenes of Other Times (Part II),' a murderer is haunted by the ghost of the person he had murdered. As Baillie writes:

Vain hope! the guilty never rest:

Dismay is always near;

There is a midnight in the breast

No morn shall ever cheer. ${ }^{22}$

But Williams's visitor is, as any reader might be, innocently passing by what turns out to be a haunted room.

Again taking as her subject the War of the Roses, Williams expands on Gray's reference in 'The Bard' to 'Ye Towers of Julius, London's lasting shame,/ With many a foul and midnight murther fed. ${ }^{23}$ The ghost of Henry VI narrates the first half of the poem, guiding the visitor past murderous apparitions. Following the accepted view, reiterated in Volume II of Hume's History of England, ${ }^{24}$ that Richard III arranged the murder of his nephews, Williams depicts the bravery of the boys as Edward V, accepting his own death, pleads for the life of his young brother, the Duke of Clarence. Then, Henry VI disappears, and another 
ghost appears, that of a later victim, Sir Thomas Overbury (1581-1613), who was poisoned in the Tower. Things get worse when the visitor is beckoned by another ghost and instead of running away is compelled to follow:

Yon bloody phantom waves his hand,

And beckons me to deeper gloom -

Rest, troubled form! I come -

Some unknown power my step impels

To horror's secret cells - (2:37)

This unknown phantom presents other ghostly visions almost as if he were doing the visitor a favour - 'For thee I raise this sable pall'(2:38) - revealing 'A mangled regal race,' which includes, as the writer in Monthly Review noted, a gruesome picture of a starving mother and child. Then the phantom points to another unnamed ghost, whose 'white beard streams with blood' (2:40), and who stares at a large purple drop, which the visitor is curious about. But the phantom warns 'Ask no more its source to know - Ne'er shall mortal eye explore/ Whence flow'd that drop of human gore' (2:40). The horrors of death are all but tangible at this point, when the phantom presents one last sight, which evokes the terror of the shapeless Death in Paradise Lost and again is shrouded in obscurity: 'A horror, nature hates to name!' (2:41). Though cautioned only to look once, the visitor, with a 'frantic eye' looks back and is left 'speechless' as two sullen shades ominously approach. The text ends at this point of indeterminacy, effectively evoking the terror which Burke associates with the sublime. In his Philosophical Enquiry into the Origin of Our Ideas on the Sublime and the Beautiful, Burke explains that

To make any thing very terrible, obscurity seems in general to be necessary. When we know the full extent of any danger, when we accustom our eyes to it, a great deal of the apprehension vanishes. Every one will be sensible of this, who considers how greatly night adds to our dread, in all cases of danger, and how much the notions of ghosts and goblins, of which none can form clear ideas, affect minds, which give credit to the popular tales concerning such sorts of being.... It is our ignorance of things that causes all our admiration, and chiefly excites our passions. ${ }^{25}$

Terror is heightened in the second half and particularly the ending of Williams's poem because the events are more obscure. The ghosts are unnamed, their deeds unknown, the fate of the visitor unclear. In the 
first half, Williams is working with historical materials that people already know about. But the events are still controversial, due to conflicting reports and to the horror of the crime of murder itself. British history, then, can be the stuff of nightmares, and Williams needs only to invent part of her story, for real horrors have already worked on the popular imagination.

In her longest poem, the 1,500-line Peru, Williams again combines an interest in the past and a concern for human suffering. As in Edwin and Eltruda and 'An American Tale,' Peru focusses on domestic tragedy, this time caused by the senseless violence of imperialism. After the dedicatory poem to Mrs. Elizabeth Montagu, Canto I opens with a glowing description of Peru and its leaders, where all is well until the arrival of Pizarro. Williams's feminization of the landscape emphasizes the rapacity of the Spaniards who 'Rend her [Peru's] soft robe, and crush her tender form' $(2: 66){ }^{26}$ The main story line of each of the remaining five cantos centres on the disruption of a particular native family. For example, in Canto II Ataliba is murdered in his cell, and his beloved Alzira kills herself; in Canto III a Peruvian priest is tortured to death, and his daughter Zilia dies of grief; in Canto VI, Cora tries to find her husband, Capac, a Peruvian chief, but she dies of exhaustion when they finally find one another: 'Long, long she wandered, till oppressed with toil,/ Her trembling footsteps track with blood the soil' (2:157). Peru is awash with bloody scenes, purple torrents, and fields of gore. The only reprieve, and it is an important one, is the love of the central Peruvian figures. Williams provides no happy endings, but her heroes and heroines have something which their murderers do not have: sensibility. Pizarro, the leader of the massacre, exemplifies the hardness of heart of one who is immune to sensibility. He dies, unloved, with no one to mourn him, 'Denied those drops that stay the parting breath,/ That soothe the spirit on the verge of death' (2:167). In contrast, Sensibility herself comes to mourn the death of the benevolent Peruvian, Las Casas.

While Peru was generally well received, one reviewer criticized Williams for her distorted historical account. Looking unfavourably on her tales of parted lovers, the reviewer pointed out that 'Love and the happy death of lovers, some self-murdered and some dying of pure grief, are the chief business of every Canto; and one half of such stories might either be left out, or twenty more added. ${ }^{27}$ The scant narration and paucity of characterization in Peru invite this kind of criticism. Williams's style results in an abstractness which has led some critics to consider her work part of a mindless cult of feeling. As recently as 1980, James Averill charged that 'scenery and suffering are equally interesting to her: the exotic and pathetic are both satisfactory sources of the excitement she craves. ${ }^{28}$ Averill unjustly implies that Williams is using 
scenes of suffering simply for a cheap effect. He ignores the literary merits of her work and her commitment to political and religious reform. Averill is correct that Williams was interested in the response that scenes of human misery evoked, but for her the response was important because it would move people to act against injustice. As a woman, she was excluded from many avenues of meaningful action, but her poetry was a means for her to express her abhorrence of despotism, slavery, and war. Not permitted to make speeches in parliament or give sermons in church, Williams voices her concern in poetic tales that depict human tragedy. She used sensibility to promote her liberal political views. For example, Peru is a response to the native revolt against the Spaniards during the early 1780s. The poem ends with a call for freedom: ' $\mathrm{O}$ Freedom, may thy genius still ascend/ Beneath thy crest may proud Iberia bend' (2:177). In one note, Williams refers explicitly to the activities of the native leader Topa Amaru II who led the uprising in 1780: 'An Indian descended from the Inca's [sic], has lately obtained several victories over the Spaniards, the gold mines have been for some time shut up; and there is much reason to hope, that these injured nations may recover the liberty of which they have been so cruelly deprived' (2:176).

Williams defends the importance of concentrating on incidents of injustice and suffering in her ode 'To Sensibility,' also included in her collection of 1786 . As early as 1759 , Frances Greville criticized sensibility in 'A Prayer for Indifference,' and as late as 1782 Hannah More argued against Greville's objections in 'Sensibility: An Epistle to the Honourable Mrs. Boscawen.' Over a period of thirty years, sensibility was still a relevant topic for debate and Williams sided with the supporters, borrowing heavily from the language of Hannah More's poem. ${ }^{29}$ Depicting herself as a religious acolyte worshipping at the shrine of sensibility, Williams stresses at the outset that she does not seek any exemption from its negative aspects; she accepts both the 'transport' and the 'woe' (1:21). But she recognizes that for many people the emotional volatility associated with sensibility is its chief drawback. Acknowledging this, Williams describes the experience of an exemplary woman of sensibility. This woman has a keener sense of pain, she bleeds to heal others' wounds, and she can never be cured of her grief at a loved one's death. The metaphors of illness suggest the physical suffering that can result from emotional anguish. In moments of solitude, the woman reflects on the burdens of all this 'fellow feeling':

She oft will heave a secret sigh,

Will shed a lonely tear, 
O'er feelings nature wrought so high,

And gave on terms so dear. (1:26)

This private dissatisfaction may represent her frustration at being excluded from more active modes of protest.

In this confession of pain, Williams draws a parallel between this woman of sensibility and Frances Greville, who sought an escape from the pains of sensibility in 'A Prayer for Indifference.' Tormented by 'shattered nerves,' and 'wounds, which now each moment bleed,' Greville asks the fairy Oberon to take her 'treacherous sense' away, but her request seems only half-serious. ${ }^{30}$ Though Williams may have modelled her choice of the ballad stanza on Greville's, she did not copy Greville's tone, which, as we see from the opening stanza, is light-hearted:

Oft I've implored the gods in vain,

And prayed till I've been weary;

For once I'll try my wish to gain

Of Oberon, the fairy. ${ }^{31}$

Greville uses humour to make light of the difficulties associated with sensibility. Perhaps this is a tactic which enables her to present her plea for a respite from caring while at the same time she can defend herself against charges of cold-heartedness. Williams earnestly takes Greville's criticism at face value and attempts to persuade her that the ease of indifference, though envied by some, is too dearly bought, for it means the loss of 'friendship, sympathy, and love,/ And every finer thought' (1:28). She considers sensibility as compassionate responsiveness, which provides a foundation for human relationship. By stressing the communal nature of sensibility, Williams implies that it is Greville's social and moral responsibility to care for others, not only in the home but in the public sphere.

Tears - traditionally used by women to gain some power in situations over which they were otherwise powerless - have a function outside the domestic environment. Williams asks: 'Who, for her apathy, would lose/ The sacred power to weep?' (1:26). Weeping is a sacred power, a gift of God. But what power could be accorded those who wept? Could they change the world? Williams believed that sensibility could cut across barriers of gender and class, and make compassion a guiding principle for human society. Todd explains that people sometimes saw sensibility 'as equalizing since it occurred in all ranks; at other times they considered it a property more or less exclusively of the higher and more genteel orders. ${ }^{32}$ Williams, an ardent Republican, does not 
emphasize class distinctions. When she mentions 'some vulgar mind' who does not understand sensibility, she uses the word 'vulgar' to mean 'ignorant,' and she generously suggests that such a person may be 'unconscious' of the effects of his or her actions (1:25). In contrast, Hannah More in her poem, which is written in heroic couplets and filled with sycophantic praise of her fellow bluestockings, arrogantly mocks those who do not appreciate the experience:

Let not the vulgar read this pensive strain,

Their jests the tender anguish wou'd prophane,

Yet these some deem the happiest of their kind,

Whose low enjoyments never reach'd the mind. ${ }^{33}$

Her references to the 'vulgar' do imply a value judgement suggesting a class of people who are ill-bred or not of good, i.e. propertied, society. In addition More differentiates between those who truly express sensibility and those who are charlatans, despite their 'exclamations, tender tones, and tears. ${ }^{34}$ She is right to express judicious discernment, but her ridicule, though humorous, is sweeping:

There are, who fill with brilliant plaints the page,

If a poor linnet meet the gunner's rage;

There are, who for a dying fawn deplore,

As if friend, parent, country, were no more;

Who boast quick rapture trembling in their eye,

If from the spider's snare they snatch a fly. ${ }^{35}$

For More, any sympathy for animals is as silly as worrying about a fly in a spider's web. One can only imagine how she would scorn Williams's Eltruda who 'replac'd / The linnet's falling nest' (1:69)! More's snobbery and biting sarcasm differ considerably from Williams's benevolent, albeit naive, idealism.

The differences in their evaluation are also significant in terms of their religious and political affiliations. More's ambivalence about sensibility foreshadows her movement towards a rigid Evangelical faith, which was based on a careful dispensation of charity that would not encourage political reform. In this poem, she emphasizes that sensibility's proper sphere is the private, not the public: 'There, Sensibility, thou best may'st reign,/ Home is thy true legitimate domain. ${ }^{36}$ Williams, on the other hand, found the concept of sensibility compatible with her Unitarian commitment to religious and political reform, and she continued to 
embrace sensibility as a life-long supporter of the ideals of the French Revolution. Williams's poem is a confident and earnest defence of sensibility, focusing on it as an equalizing force. In one of her paraphrases from scripture she considers the passage from Matthew 7:12: 'Whatsoever ye would that men should do to you, do ye even so to them.' If people were to follow this 'sacred rule of action,' Williams writes, 'No more the powerful would the weak oppress' (1:113). Her devotion to this principle led her to write poems of sorrow which would, in her words, 'teach the selfish breast what others feel' (1:113). Williams politicized sensibility in her poetry. Like many Protestant Dissenters, her religious conscience led her to consider public issues. As a celebrated poet in the 1780s, she had good reason to hope that her dream of a world free of oppression could come true.

\section{DEBORAH KENNEDY}

Mount Saint Vincent University

\section{Notes}

1 Janet Todd, Sensibility: An Introduction (London: Methuen, 1986) 11.

2 Williams's 'On the Death of the Rev. Dr. Kippis' is reprinted in Eighteenth-Century Women Poets: An Oxford Anthology, ed. Roger Lonsdale (Oxford: Oxford UP, 1989) 418-20.

3 All other references to Helen Maria Williams's poetry are to Poems 2 vols. (London: Thomas Cadell, 1786). Volume and page number will be cited in the text.

4 Syndy McMillen Conger, The Sorrows of Young Charlotte: Werther's English Sisters, 1785-1805,' Goethe Yearbook 3 (1986): 32.

5 Conger 32.

6 M. Ray Adams, 'Helen Maria Williams and the French Revolution,' Wordsworth and Coleridge: Studies in Honour of George McLean Harper, ed. Earl Leslie Griggs (New York: Russell, 1967) 93.

7 For a brief but excellent overview of Williams's career see Adams, 87-117. For a fuller account see the biography Hélène-Maria Williams et ses amis, by Lionel D. Woodward (Paris: Librairie Ancienne Honoré Champion, 1930. Geneva: Slatkine, 1977).

8 Northrop Frye, 'Towards Defining an Age of Sensibility,' Fables of Identity (New York: Harcourt, 1963) 130-37.

9 Hugh Blair, A Critical Dissertation on the Poems of Ossian, the Son of Fingal (London, 1763) 21.

10 Blair 70-71. 
11 Steven D. Cox, 'The Stranger Within Thee': Concepts of the Self in Late-Eighteenth-Century Literature (Pittsburgh: U of Pittsburgh P, 1980).

12 Virginia Woolf, Three Guineas (1938. London: Hogarth, 1986) 7.

13 This deprecation of her intellect continued in her early prose writings, though she gained more confidence in her later career. In her first book on France she explains that she had never intended nor deemed herself suited to write about politics: 'how difficult should I have found it to arrange arguments and inferences in the cells of my brain! But however dull the faculties of my head, I can assure you that when a proposition is addressed to my heart, I have some quickness of perception.' Letters Written in France, in the Summer 1790 (London:T. Cadell, 1790) 195-96. By 1815 she is much more sure of herself and her qualifications: 'I shall trace, as you desire, in a series of letters, the events which are passing before me ... I may at least pretend to be qualified for the task inasmuch as it respects a knowledge of the subject - I who, during my residence in Paris, have witnessed all the successive phases of its revolutions, who have so long marked the list of its remembrances, its calamities, its triumphs, and its crimes!' Narrative of Events which Have Taken Place in France from the Landing of Napoleon Bonaparte on the First of March, 1815, till the Restoration of Louis XVIII (1815. Cleveland, 1895) 3.

14 Thraliana, ed. Katharine C. Balderston (Oxford: Clarendon, 1951) 2: 730.

15 For an overview of the pacifist and militaristic poetry of the eighteenth century see J. Walter Nelson, 'War and Peace and the British Poets of Sensibility,' Studies in Eighteenth-Century Culture 7(1978): 345-66.

16 John Scott's ode is reprinted in Eighteenth-Century English Literature, ed. Geoffrey Tillotson et al. (New York: Harcourt, 1969) 1530.

17 'An Ode to Mars' is reviewed in The Monthly Review 60 (1779): 65-66.

18 David V. Erdman, ed. The Complete Poetry \& Prose of William Blake (New York: Anchor, 1982) 439.

19 John Butt, The Mid-Eighteenth Century, ed. Geoffrey Carnall (Oxford: Clarendon, 1979) 99.

20 Patricia Meyer Spacks, The Insistence of Horror: Aspects of the Supernatural in Eighteenth-Century Poetry (Cambridge: Harvard UP, 1962) 117.

21 Monthy Review 75 (1786): 49.

22 Joanna Baillie, 'Night Scenes of Other Times (Part II),' Eighteenth-Century Women Poets 435.

23 Thomas Gray, 'The Bard,' Gray and Collins: Poetical Works, ed. Roger Lonsdale (Oxford: Oxford UP, 1977) 56.

24 Horace Walpole's defence of Richard III in Historic Doubts (1768) was justly attacked in the press and obviously failed to convince Williams.

25 Edmund Burke, A Philosophical Enquiry into the Origin of Our Ideas on the Sublime and the Beautiful, ed J.T. Boulton (London: Routledge, 1958) 58-61.

26 Janet Todd discusses this point in Sensibility 60.

27 The European Magazine 10 (1786): 180.

28 James Averill, Wordsworth and the Poetry of Human Suffering (Ithaca: Cornell UP, 1980) 31. 
29 Stuart Curran discusses other poems on sensibility in 'Romantic Poetry: The I Altered,' Romanticism and Feminism, ed. Anne K. Mellor (Bloomington: Indiana UP, 1988) 185-207.

30 Frances Greville, 'A Prayer for Indifference,' Eighteenth-Century Women Poets 193.

31 Greville 192.

32 Todd, Sensibility 13.

33 Hannah More, The Works of Hannah More. A New Edition in Eighteen Volumes (London: T. Cadell and W. Davies, 1816) 1:174.

34 More 1:181.

35 More 1:181.

36 More 1:184. 